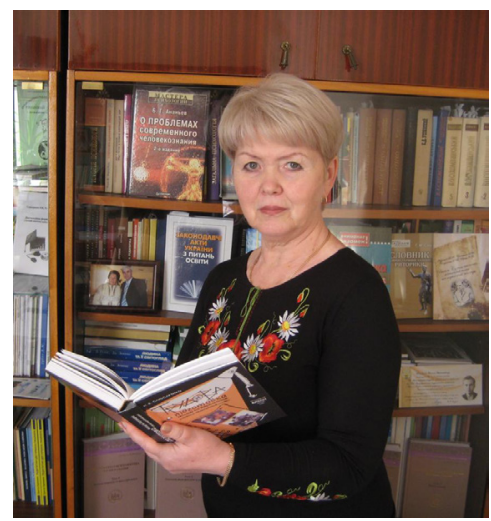

\author{
Ніна Слюсаренко, \\ доктор педагогічних наук, професор кафедри \\ педагогіки та психології, \\ Херсонський державний університет \\ (м. Херсон, Україна)
}

\author{
Nina Slyusarenko, \\ Doctor of Pedagogical Sciences, Professor, \\ Department of Pedagogy and Psychology, \\ Kherson State University \\ (Kherson, Ukraine) \\ ninaslusarenko@gmail.com

\title{
ПРОБЛЕМИ ОРГАНІЗАЦІЇ ПРОФІЛЬНОГО НАВЧАННЯ В МАЛОКОМПЛЕКТНИХ ШКОЛАХ УКРАЇНИ ПОЧАТКУ ХХІ СТОЛІТТЯ
}

Анотація. У статті наголошено, що на початку третього тисячоліття проблема освіти учнів сільських шкіл почала виходити далеко за межі освітянської галузі, оскільки згортання діяльності сільських малокомплектних шкіл може призвести до «вимирання» села.

Поставлено за мету проаналізувати проблеми організації профільного навчання в малокомплектних школах України початку XXI століття. 3 цією метою використано такі методи дослідження: аналіз джерельної бази з проблеми дослідження; понятійно-термінологічний аналіз, синтез та порівняння різних трактувань поняття «малокомплектна школа»; вивчення вітчизняного досвіду організації профільного навчання молодого покоління та шляхів його вдосконалення.

Виявлено, що термін «малокомплектна школа» в науковому обігу використовується впродовж багатьох десятиліть, переважно стосовно сільських початкових шкіл, де вчителів менше, ніж класів, і кожен учитель працює одночасно з двома чи кількома класами, або неповних середніх та середніх шкіл з малою наповнюваністю класів чи відсутністю деяких класів.

Проаналізовано нагальну для сільської школи проблему організації профільного навчання учнів та шляхи її вирішення (налагодження взаємодії між різними загальноосвітніми навчальними закладами; надання особливого значення опорним профільним школам; створення в опорних профільних школах належних умов для реалізації навчальних програм профільного навчання за кількома напрямами та ін.).

Акцентовано на необхідності збільшення уваги до сільської (в тому числі малокомплектної) школи та детального її вивчення, до здобутків сільських шкіл України щодо організації трудової підготовки учнів у попередні історичні періоди. Зроблено висновок, що пошук шляхів удосконалення діяльності малокомплектних шкіл, відродження традицій виробничого навчання і трудового виховання в них сільської молоді є перспективним для подальшого наукового пошуку.

Ключові слова: малокомплектна школа, сільська малокомплектна школа, опорна профільна школа, виробниче навчання, профільне навчання.

\section{PROBLEMS OF ORGANIZING PROFESSION-ORIENTED EDUCATION IN UNGRADED SCHOOLS OF UKRAINEAT THE BEGINNING OF THE XXI CENTURY}

Abstract. The article states that at the beginning of the third millennium, the problem of education of rural school pupils began to go far beyond the educational sphere, since the curtailment of rural ungraded schools could lead to «the extinction» of the village.

The goal is to analyse the problems of organization of profession-oriented education in ungraded schools of Ukraine at the beginning of the XXI century. For this purpose, the following research methods have been used: the analysis of the source base concerning the research problem; the conceptual and terminological analysis, synthesis and comparison of different interpretations of the concept of «an ungraded school»; the study of domestic experience in organizing professionoriented education of the younger generation and ways to improve it.

It has been found that the concept «an ungraded school» has been used in scientific research for many decades, mainly for rural primary schools where teachers are less than classes, and each teacher works with two or more classes, or incomplete secondary schools or secondary schools with low filling capacity classes or lack of some classes.

The problem of organizing profession-oriented education of pupils and the ways of solving it (the establishment of interaction between different general educational institutions; the provision of special significance to the basic professionoriented schools; the creation of proper conditions for the implementation of the curriculum of profession-oriented education in several areas; etc.) has been analysed.

It has been emphasised on the necessity to increase the attention of the village (including the ungraded) school and its detailed study to the achievements of rural schools in Ukraine regarding the organization of pupils' vocational training in 
previous historical periods. It has been concluded that the search for ways to improve the activities of ungraded schools, the revival of the traditions of production training and the labour education of rural youth is promising for further scientific research.

Keywords: ungraded school, rural ungraded school, basic profession-oriented schools, production training, professionoriented education.

\section{ВСТУП}

Постановка проблеми. На початку XXI століння малокомплектна школа все більше і більше привертає увагу значного числа науковців, педагогів-практиків, керівників освіти різного рівня та широкого кола громадськості. Зокрема, викликає неабияке занепокоєння як існування, так і згортання діяльності таких закладів освіти.

Перше пов'язане з тим, що витрати на навчання одного учня в малокомплектних школах завеликі. Так, наприклад, у 2014-2015 навчальному році вони складали від 8,6 тис. грн. (Одеська обл.) до 15,1 тис. грн. (Івано-Франківська обл.). Така ситуація склалася внаслідок різкого зменшення кількості учнів. Їх чисельність скоротилася від 7,1 млн (1991-1992 н. р.) до 3,9 млн (2017-2018 н. р.).

Тому виявляється цілком логічним закриття шкіл з малою кількістю учнів та створення у відповідності до «Положення про освітній округ», затвердженого постановою Кабінету Міністрів України від 27.08.2010 року № 777, так званих опорних закладів освіти, які дозволяють зменшити бюджетні витрати на школи.

Разом із тим, згортання діяльності малокомплектних шкіл, які переважно функціонують у невеличких селах, може призвести (а подекуди і призводить) до «вимирання» останніх. Саме тому порушена проблема є актуальною і потребує невідкладного розв'язання.

Аналіз останніх досліджень і публікацій. В останні десятиліття XX - на початку XXI століття різні аспекти організації освітнього процесу в малокомплектній школі стали предметом дослідження в таких дисертаціях: Г. Суворова «Основные направления совершенствования учебно-воспитательного процесса в малокомплектной начальной сельской школе» (1984); А. Кірьянов «Педагогическая диагностика воспитательного процесса в малокомплектной сельской школе» (1991); Г. Тришнівська «Организация внеурочной воспитательной деятельности учеников начальных малокомплектных школ» (1991); С. Кулікова «Взаимосвязь учебного и свободного времени в формировании экологической культуры подростков (на материале деятельности сельских малокомплектных школ)» (1993); Л. Титаренко «Формирование самоконтроля младших школьников в условиях малокомплектной школы» (1993); С. Новіков «Методические основы эстетического воспитания учащихся сельских малокомплектных школ средствами народного декоративно-прикладного искусства» (1995); В. Семенов «Особенности становления и развития воспитательной системы сельской малочисленной школы» (1998); В. Мелешко «Управління малокомплектними початковими школами різної структури» (2002) та ін.

Досить широке відображення проблеми малокомплектних шкіл знайшли у наукових та науково-методичних працях О. Савченко. Це такі одноосібні роботи вченої: «Планування навчального процесу в малокомплектній школі», «Урок у малокомплектній» (1973); «Організація навчального процесу в малокомплектній школі», «Структура уроку в малокомплектній школі» (1974); «Піднесення якості уроку в малокомплектній школі», «Уроки російської мови в малокомплектній школі», «Условия повышения эффективности самостоятельной работы учащихся малокомплектной школы» (1977); «Комплексное исследование проблем малокомплектной начальной школы» (1982); «Вдосконалення навчально-виховного процесу в малокомплектних школах» (1995); «Навчальновиховний процес у малокомплектній школі» (2001). До того ж свого часу вийшло друком кілька праць Олександри Яківни у співавторстві: «Великі турботи малих шкіл» (співавтор М. Парфьонов, 1972); «Організація методичної роботи учителів малокомплектних шкіл» (співавтори Н. Коваль та Л. Іноземцева, 1975); «Навчально-виховний процес у малокомплектній школі» (співавтор Г. Суворова, 1987, 1988): «Структурування навчальних програм для проведення однотемних та інтегрованих уроків у малокомплектній школі» (співавтори Н. Присяжнюк та П. Мельничук, 1993).

Значну увагу діяльності малокомплектних шкіл у своїх дослідженнях приділили: Н.Касярум, Л. Прокопів, Л. Стасюк та ін.

МЕТА I ЗАВДАННЯ ДОсЛІДЖЕНнЯ. Мета статті - проаналізувати проблеми організації профільного навчання в малокомплектних школах України початку XXI століття.

МЕТОДИ ДОслІДЖЕНня: аналіз джерельної бази з проблеми дослідження; понятійно-термінологічний аналіз, синтез та порівняння різних трактувань поняття «малокомплектна школа»; вивчення вітчизняного досвіду організації профільного навчання молодого покоління та шляхів його вдосконалення.

\section{РЕЗУЛЬТАТИ ДОСЛІДЖЕННЯ}

Термін «малокомплектна школа» в науковому обігу використовується впродовж багатьох десятиліть. Його тлумачення знаходимо ще в «Педагогічному словнику» 1960 року видання, де сказано, що малокомплектна школа - це початкова школа, в якій учителів менше, ніж класів, і кожен учитель працює одночасно з двома чи кількома класами. У словнику також зазначено, що в однокомплектній школі один учитель навчає учнів усіх чотирьох класів, у двокомплектній - два вчителя працюють в двох классах одночасно, у трикомплектній - два вчителі працюють кожен в одному з класів, а третій - у двох класах. Такі школи розміщуються в тих населенних пунктах, де бракує учнівського контингенту, щоб організувати звичайну початкову школу з чотирма повними класами («Педагогический словарь», 1960, с. 652-653). 
Інші лексикографічні джерела, що вийшли друком в наступні роки (Гончаренко С. У., 2011, с. 270; «Педагогічний словник», 2001, с. 304; «Психолого-педагогический словарь для учителей и руководителей общеобразовательных учреждений», 1998, с. 239), подають тотожні або аналогічні визначення поняття «малокомплектна школа». Однак у «Педагогічному словнику» за ред. М. Ярмаченка уточнюється, що такі заклади освіти в багатьох країнах знаходяться переважно в сільській місцевості, що в 70-ті роки XX століття це поняття почало охоплювати й «неповні середні та середні школи з малою наповнюваністю класів, у яких часто відсутні деякі класи взагалі» («Педагогічний словник», 2001, с. 304).

Підкреслимо, що на початку третього тисячоліття проблема освіти учнів сільських шкіл почала виходити далеко за межі освітянської галузі. Так сталося тому, що на селі освіта традиційно відіграє значно більшу роль, ніж у містах. Школа тут виступає в якості осередку культури, цивілізації, гаранта стабільного розвитку. Це чи не єдиний освітньо-виховний і культурний центр на селі. Сьогодні «хороша сільська школа є предметом гордості, свідченням добробуту й соціального благополуччя суспільства, міцності селянської общини». Тому її можна розглядати «не просто як освітній заклад, а як системний чинник відродження українського села» («Стан та соціальний захист сільських дітей», 2005, с. 76).

Разом із тим, «хороша сільська школа» - явище, яке нині зустрічається не так часто, як хотілося б. Тому для села все більш актуальною стає проблема доступності для молоді доброякісної освіти. 3 одного боку, Національна доктрина розвитку освіти у XXI сторіччі передбачає забезпечення рівного доступу всіх громадян України до доброякісної освіти, а з іншого, можливості сільської молоді здобути таку освіту дещо обмежені. Зазначене передусім стосується шкільної освіти (Слюсаренко Н. В., 2008).

На цьому, зокрема, наголошено в тематичній державній доповіді про становище дітей в Україні за підсумками 2004 року, де сказано: «Спостерігається суттєва різниця в рівні загальноосвітньої підготовки, яку отримують учні міських і сільських шкіл» («Стан та соціальний захист сільських дітей», 2005, с. 84]. Зазначене пояснюють тим, що сільські школи, як і раніше, відчувають значні труднощі в організації навчально-виховного процесу, забезпеченні кадрами, матеріально-технічному оснащенні тощо.

Як наслідок, виникають усілякі негаразди. Наприклад, у сільських школах діти отримують реальні знання, рівень яких є нижчим, ніж в учнів міських поселень. Це має неабияке значення, адже визначає соціально-професійні орієнтації сільської молоді, впливає на соціальний склад студентів та позначається на освітньо-професійній характеристиці сільського населення. Так, проведений аналіз соціологічних даних щодо професійного вибору молодих людей із різних типів поселень показує, що «сільська молодь значно більше зорієнтована на професії, які не вимагають високого освітнього рівня на початку трудової діяльності або здобуття яких не зумовлене тривалим періодом навчання». Учні сільських шкіл, які обирають професії, пов'язані з працею в сільському господарстві, у більшості випадків залишають загальноосвітні школи після отримання базової середньої освіти та продовжують навчання в професійно-технічних закладах. Однак у сільській місцевості працевлаштування випускників загальноосвітніх шкіл і професійно-технічних училищ є досить проблемним («Стан та соціальний захист сільських дітей», 2005, с. 89-90).

Нагальною для сільської школи є проблема організації виробничого навчання учнів, що здобувають професії сільськогосподарського виробництва, у першу чергу механізаторські. Подолати цю проблему можна було б шляхом створення регіональних навчально-практичних центрів, де учні мали б можливість ознайомлюватися 3 новими технологіями виробництва, організацією роботи приватних фермерських підприємств, зразками нової техніки. Разом із тим, такі центри не можуть функціонувати без наявності в них нової техніки, насамперед вітчизняного виробництва. Але державним бюджетом України впродовж багатьох років кошти на її придбання не передбачалися. Водночас деякі сільські підприємства різних форм власності мають таку техніку. Тому керівникам закладів освіти слід провести роботу щодо залучення техніки названих підприємств для навчання учнів на основі взаємовигідних договорів («Стан та соціальний захист сільських дітей», 2005, с. 90).

У цьому контексті необхідно також звернути увагу на інформацію, наведену в рішенні колегії Міністерства освіти України № 14/8-3 від 28 жовтня 1998 року «Про стан та перспективи розвитку загальноосвітніх навчальних закладів у сільській місцевості». Тут сказано, що протягом останніх років XX століття не проводилось оновлення навчального обладнання майстерень сільських шкіл, а діяльність МНВК (їх у сільській місцевості у 1998 році було 130), стан їх матеріально-технічного забезпечення та фінансування викликає занепокоєння. До того ж, «незважаючи на те, що загальноосвітні навчальні заклади сільської місцевості повинні привчати дітей до господарювання на землі, мати при школах підсобні господарства, як це було 5-10 років тому, то в даний час понад 1500 шкіл I-III ступеня не мають навіть навчально-дослідних ділянок і лише 405 шкіл мають підсобні господарства» («Про стан та перспективи розвитку загальноосвітніх навчальних закладів у сільській місцевості», 1999 , с. 10).

Ще однією проблемою є те, що підготовка робітників із числа сільської молоді здійснюється за досить обмеженим переліком професій. Проте для продуктивної зайнятості сільського населення перелік професій необхідно розширювати. Це особливо стосується професій переробного профілю, сфери послуг для села, сільського будівництва («Стан та соціальний захист сільських дітей», 2005, с. 90).

Проблема профільного навчання сільської молоді знайшла відображення у «Білій книзі національної освіти України» (2009), де, зокрема, сказано, що «сільські середні загальноосвітні школи не в змозі самотужки розв'язати проблему профільного навчання, оскільки мають обмежені виховні й розвивальні можливості, 
особливо це стосується малокомплектних шкіл» («Біла книга національної освіти України», 2009, с. 157). У зв'язку з цим запропоновано:

- налагодити «взаємодію різних загальноосвітніх навчальних закладів, обмін та спільне використання матеріальних, науково-методичних і кадрових ресурсів»;

- надавати особливого значення опорним профільним школам - закладам освіти, що створюються «на базі загальноосвітніх навчальних закладів I-ІІІ ступенів, які мають необхідну матеріально-технічну базу, кадрове забезпечення і знаходяться у межах територіальної доступності для учнів інших закладів»;

- створити в опорних профільних школах «умови для реалізації навчальних програм профільного навчання за кількома напрямами», які необхідно визначати «згідно з інтересами учнів та їхніх батьків з огляду на потреби місцевого ринку праці, замовлення регіону на підготовку фахівців для сфери економіки»;

- організувати у сільських школах з малою наповнюваністю учнів (без паралельних класів) «різновікові динамічні профільні групи (10-11-ті класи), профільні групи за одним напрямом профільного навчання (за наявності відповідних матеріальних, кадрових умов, а також із завважуванням потреб учнів і соціального замовлення)»;

- реалізувати програми профільного навчання сільської молоді шляхом створення «освітнього округу, що дає змогу ефективно використовувати матеріальні й кадрові ресурси, концентрувати їх для задоволення освітніх потреб кількох шкіл»;

- створити міжшкільні профільні групи на базі опорних профільних шкіл, навчально-виховні комплекси, міжшкільні навчально-виробничі комбінати задля «надання якісних освітніх послуг, здійснення допрофесійної та початкової професійно-кваліфікаційної підготовки» («Біла книга національної освіти України», 2009, с. 157-158).

У «Білій книзі національної освіти України» також наголошено, що «почасти заклад не може реалізувати запити всіх випускників 9-х класів щодо вибору профілів навчання через обмеженість фінансування і неспроможність утримувати класи з невеликою наповнюваністю. Натомість учні не хочуть втрачати класні колективи, до яких звикли і в яких їм комфортно навчатися. Тому не завжди навчання в класах певних профілів зумовлює вибір вищих або професійно-технічних навчальних закладів» («Біла книга національної освіти України», 2009, с. 157-158).

\section{ВИСНОВКИ ТА ПЕРСПЕКТИВИ ПОДАЛЬШИХ ДОСЛІДЖЕНЬ}

Отже, наявність цих та інших проблем указує на необхідність збільшення уваги до сільської (в тому числі малокомплектної) школи та детального її вивчення. Наприклад, пильної уваги потребують колишні здобутки сільських шкіл України щодо організації трудової підготовки учнів. Вони доводять, що на селі можна досить успішно здійснювати підготовку учнів до трудової діяльності, а також профільне навчання. Однак сьогодні у цій справі більше негараздів, ніж позитивного досвіду. На це свого часу вказував І. Ткаченко, який, зокрема, писав: «А що маємо сьогодні? Хто буде вирощувати хліб у XXI столітті? Яка роль сільської школи в нових умовах соціально-економічного середовища на селі? Яким має бути нове покоління молодих хліборобів, що поєднувало б у своїй практичній діяльності трудові традиції батьків, дідів, прадідів з надбаннями науково-технічного прогресу в сільському господарстві, новими прогресивними технологіями і формами оплати праці? Чи, може, тепер це не $€$ однією із функцій сільської школи?» (Іванко А. Б., 2003, с. 46; Іванко А. Б., 2004, с. 96-97).

Пошук шляхів удосконалення діяльності малокомплектних шкіл, відродження традицій виробничого навчання і трудового виховання в них сільської молоді $€$ перспективним для подальшого наукового пошуку.

\section{СПИСОК ВИКОРИСТАНИХ ДЖЕРЕЛ}

Біла книга національної освіти України. (2009) / Акад. пед. наук України; за ред. В. Г. Кременя. URL: http://www. ukraine3000.org.ua. Гончаренко, С. У. (2011).Український педагогічний енциклопедичний словник. Видання друге, доповнене й виправлене. Рівне : Волинські обереги.

Донченко, К. Коли почнуть закривати школи у об'єднаних громадах. URL: https://biz.censor.net.ua/resonance/3077950/ koli_pochnut_zakrivati_shkoli_u_obdnanih_gromadah

Іванко, А. Б. (2003). В. О. Сухомлинський, І. Г. Ткаченко: діалог самодостатніх педагогічних систем. 2-е вид. Кіровоград : Центрально-українське вид-во.

Іванко, А. Б. (2004). Освітня діяльність та педагогічна спадщина І. Г. Ткаченка. Кіровоград : Поліграф-Терція.

Педагогический словарь : в 2 т. (1960) / под ред. И. А. Каирова (гл. ред.), Н. К. Гончарова, Н. Д. Казьмина [и др.]. М. : Из-дво АПН, Т. 1.

Педагогічний словник (2001). / за ред. М. Д. Ярмаченка. К. : Пед. думка.

Про стан та перспективи розвитку загальноосвітніх навчальних закладів у сільській місцевості, (1999). Інформаційний збірник Міністерства освіти України. 1, 3-16.

Психолого-педагогический словарь для учителей и руководителей общеобразовательных учреждений. (1998). / авт.-сост. В. А. Мижериков. Ростов н/Д. : Феникс.

Слюсаренко, Н. В. (2008). І. Ткаченко та проблеми трудової підготовки учнів сільських шкіл України кінця XX - початку XXI століття. Збірник наукових праць. Педагогічні науки / Херсон. держ. ун-т. Херсон, Вип. 50, ч. 1, 53-57.

Стан та соціальний захист сільських дітей: тематична державна доповідь про становище дітей в Україні за підсумками 2004 р. (2005) / авт. кол. : Т. Ф. Алексєєнко [та ін.]; Держ. ін-т проблем сім'ї та молоді. Київ. 


\section{REFERENCES}

Bila knygha nacionaljnoji osvity Ukrajiny (2009) / Akad. ped. nauk Ukrajiny; za red. V. Gh. Kremenja. Retrieved from: http://www. ukraine3000.org.ua.

Ghoncharenko, S. U. (2011). Ukrajinsjkyj pedaghoghichnyj encyklopedychnyj slovnyk. Vydannja drughe, dopovnene j vypravlene. Rivne: Volynsjki obereghy.

Donchenko, K. Koly pochnutj zakryvaty shkoly u ob'jednanykh ghromadakh. Retrieved from: https://biz.censor.net.ua/ resonance/3077950/koli_pochnut_zakrivati_shkoli_u_obdnanih_gromadah

Ivanko, A. B. (2003). V. O. Sukhomlynsjkyj, I. Gh. Tkachenko: dialogh samodostatnikh pedaghoghichnykh system. 2-e vyd. Kirovoghrad: Centraljno-ukrajinsjke vyd-vo.

Ivanko, A. B. (2004). Osvitnja dijaljnistj ta pedaghoghichna spadshhyna I. Gh. Tkachenka. Kirovoghrad : Polighraf-Tercija.

Pedaghoghycheskyj slovarj (1960) : v 2 t. / pod red. Y. A. Kayrova (ghl. red.), N. K. Ghoncharova, N. D. Kazjmyna [y dr.]. M. : Yz-dvo APN, Vol. 1.

Pedaghoghichnyj slovnyk, (2001). / za red. M. D. Jarmachenka. K. : Ped. dumka.

Pro stan ta perspektyvy rozvytku zaghaljnoosvitnikh navchaljnykh zakladiv u siljsjkij miscevosti. (1999). Informacijnyj zbirnyk Ministerstva osvity Ukrajiny. 1, 3-16.

Psykhologho-pedaghoghycheskyj slovarj dlja uchytelej y rukovodytelej obshheobrazovateljnykh uchrezhdenyj (1998). / avt.-sost. V. A. Myzherykov. Rostov n/D: Fenyks.

Sljusarenko, N. V. (2008). I. Tkachenko ta problemy trudovoji pidghotovky uchniv siljsjkykh shkil Ukrajiny kincja KhKh - pochatku KhKhl stolittja. Zbirnyk naukovykh pracj. Pedaghoghichni nauky / Kherson. derzh. un-t. Kherson, Vol. 50, ch. 1.

Stan ta socialjnyj zakhyst siljsjkykh ditej: tematychna derzhavna dopovidj pro stanovyshhe ditej v Ukrajini za pidsumkamy 2004 r. (2005) / avt. kol. : T. F. Aleksjejenko [ta in.]; Derzh. in-t problem sim'ji ta molodi. Kyiv.

Статтю подано до редколегії 01.03.2019 р.

Рекомендовано до друку 22.03.2019 р. 